University of Nebraska - Lincoln

DigitalCommons@University of Nebraska - Lincoln

2014

\title{
Artificial diets used in mass production of the New World screwworm, Cochliomyia hominivorax
}

S. R. Skoda

USDA-ARS, Steve.Skoda@ars.usda.gov

H. Chen

USDA-ARS

M. F. Chaudhurry

USDA-ARS

A. Sagel

USDA-ARS

P. L. Phillips

USDA-ARS

Follow this and additional works at: https://digitalcommons.unl.edu/usdaarsfacpub

Skoda, S. R.; Chen, H.; Chaudhurry, M. F.; Sagel, A.; and Phillips, P. L., "Artificial diets used in mass production of the New World screwworm, Cochliomyia hominivorax" (2014). Publications from USDA-ARS / UNL Faculty. 1432.

https://digitalcommons.unl.edu/usdaarsfacpub/1432

This Article is brought to you for free and open access by the U.S. Department of Agriculture: Agricultural Research Service, Lincoln, Nebraska at DigitalCommons@University of Nebraska - Lincoln. It has been accepted for inclusion in Publications from USDA-ARS / UNL Faculty by an authorized administrator of DigitalCommons@University of Nebraska - Lincoln. 


\title{
Artificial diets used in mass production of the New World screwworm, Cochliomyia hominivorax
}

\author{
H. Chen, M. F. Chaudhury, A. Sagel, P. L. Phillips \& S. R. Skoda \\ USDA-ARS, Knipling-Bushland U. S. Livestock Insects Research Laboratory, Kerrville, TX, USA
}

\author{
Keywords \\ diet formulation, insect nutrition, solidifying \\ agents, sterile insect technique, waste diet \\ management

\section{Correspondence} \\ Steve R. Skoda (corresponding author), USDA- \\ ARS, Knipling-Bushland U. S. Livestock Insects \\ Research Laboratory, 2700 Fredericksburg \\ Road, Kerrville, TX 78028, USA. \\ E-mail: steve.skoda@ars.usda.gov \\ Received: August 30, 2013; accepted: Novem- \\ ber 22, 2013. \\ doi: 10.1111/jen.12112 \\ Mention of trade names or commercial \\ products in this review paper is solely for the \\ purpose of providing specific information and \\ does not imply recommendation or \\ endorsement by the U. S. Department of \\ Agriculture (USDA). USDA is an equal \\ opportunity provider and employer.
}

\begin{abstract}
The New World screwworm, Cochliomyia hominivorax (Coquerel) (Diptera: Calliphoridae), has been eradicated from North and Central America using the sterile insect technique. This success has been based on mass production of high-quality screwworms using artificial diets since 1958. Many diet formulations for both larvae and adults have been developed, mainly driven by cost efficiency and material supply. However, only four larval and two adult diet formulations have been applied in the six sterile fly mass production plants in the USA, Mexico and Panama. Herein, we briefly review the history of screwworm diet research and development, introduce the diet formulations used in mass rearing and discuss their advantages and disadvantages in terms of plant application. Finally, we propose future research on screwworm nutrition, potential protein sources, feeding stimulants, further optimization of screwworm formulations and possible methods to reduce the negative qualities of waste generated during the mass production.
\end{abstract}

\section{Introduction}

Use of the sterile insect technique (SIT) to eradicate/ control insect pests has three requirements: (i) artificial diet for mass-rearing subject insects; (ii) sterilizing the insects; and (iii) releasing competitive sterilized insects (Graham 1985; Baumhover 2002; Mastrangelo and Welch 2012). The development of artificial diets for screwworm (Cochliomyia hominivorax) mass production, with sufficient number and adequate quality of adults, has evolved to give rise to the success of screwworm eradication in North and Central America and North Africa (Knipling 1985; FAO 1992). The diet is one of the critical and costly aspects in an eradication programme (Gingrich et al. 1971). Since the launch of the first eradication programme against screwworm in Florida in 1958, 1-500 million sterile flies per week have been produced on various artificial diets (Smith 1960; Goodenough et al. 1983; Whitten 1985; Taylor et al. 1991). Six screwworm facilities were built and operated for mass rearing: Bithlo (1958) and Sebring (1958-1959) in Florida; Kerrville (1962) and Mission (1962-1980) in Texas of USA; Tuxtla Gutierrez (1976-2012), Chiapas, Mexico (Graham 1985); and Pacora (2007-present), Panama, Republic of Panama.

The development of screwworm diet for mass rearing is driven by several factors including material price (fig. 1), supply sustainability, labour and time used to prepare the diets, preparation method, raw material storage, waste and pollution. Many formulations (table 1) of artificial diets have been used in the screwworm mass rearing, evolving from the original lean-meat-based diet (Melvin and Bushland 1936, 1940) used in Florida, to a liquid diet made from blood, milk and egg powders (Gingrich et al. 1971; 


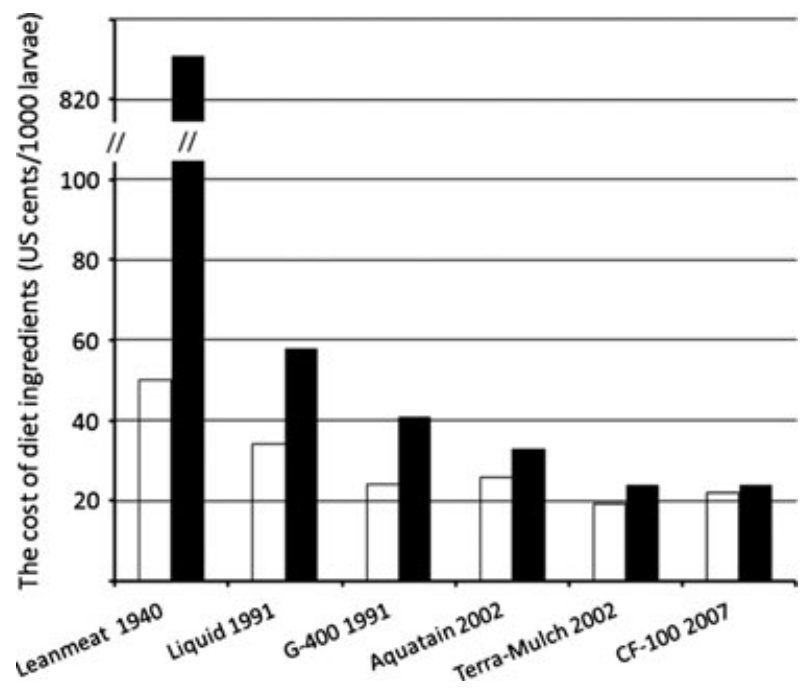

Fig. 1 The costs of ingredients in the larval diets used in the screwworm mass production over the years. The clear and black bars show the estimated prices in the publications of the years marked under the $x$ axis and the inflation-adjusted prices in 2013 , respectively.

Taylor 1988a) prepared in Texas and Mexico, followed by a gelled diet with the same nutrient powders (Taylor and Mangan 1987; Taylor 1988b; Taylor et al. 1991) applied in Mexico and Panama, and to a cellulose-fibre-based diet with the nutrient powders that was used later in the rearing plant in Mexico
(Chaudhury et al. 2002, 201 1; Chaudhury and Skoda 2007). Adult diets were also improved for the screwworm mass production (Brewer 1993; Hammack 1999; Chaudhury et al. 2000).

In this review, we introduce the formulations of plant-used diets for both larva and adult, analyse the cost trend of the larval diets used in large amount and discuss the advantages, disadvantages and relevant issues of these diets. Finally, we prospect the future of screwworm artificial diets.

\section{Artificial Diets Used in Mass Rearing}

\section{Lean-meat larval diet}

The first artificial medium, used for laboratory level rearing, was composed of $500 \mathrm{~g}$ ground lean beef, $750 \mathrm{ml}$ milk, $250 \mathrm{ml}$ citrated calf blood and $0.5 \mathrm{ml}$ formaldehyde (Melvin and Bushland 1936). They were enlightened by the observation that larvae could finish their development in guinea pig carcasses kept at high temperature and by tests showing that neonates fed on raw lean beef or hard-boiled chicken eggs maintained at $37^{\circ} \mathrm{C}$ could reach the adult stage although in a small body size. During their tests of artificial diets, they found that the decomposition of the diets caused the death of young larvae. Although the aseptic technique could solve the issue, the

Table 1 Larval and adult artificial diets applied in the screwworm mass rearing

\begin{tabular}{|c|c|c|c|c|}
\hline Diet & & Nutritional ingredient & Bulking agent & Note \\
\hline \multirow[t]{4}{*}{ Larva } & Lean-meat diet & $\begin{array}{l}\text { Lean ground meat (beef, whale or } \\
\text { horse meat) and citrated beef blood }\end{array}$ & NA & $\begin{array}{l}\text { Used in the plants in Bithlo Sebring, } \\
\text { Kerrville and Mission (Melvin and } \\
\text { Bushland 1940; Graham and Dudley } \\
\text { 1959; Smith 1960; Baumhover et al. 1966) }\end{array}$ \\
\hline & Liquid diet & $\begin{array}{l}\text { Dried whole chicken egg, dried } \\
\text { whole bovine blood, } \\
\text { calf suckle and dried } \\
\text { cottage cheese (removed later) }\end{array}$ & $\begin{array}{l}\text { Cotton or } \\
\text { acetate fibre }\end{array}$ & $\begin{array}{l}\text { Used in the Mission and Mexican } \\
\text { plants (Gingrich et al. 1971; } \\
\text { Brown and Snow 1979) }\end{array}$ \\
\hline & Gelled diet & Dried blood, dried egg and dried milk & $\begin{array}{l}\text { Water Lock }{ }^{\circledR} \mathrm{G}-400 \\
\text { or Aquatain }\end{array}$ & $\begin{array}{l}\text { Used in the Mexican or Panamanian } \\
\text { plants (Harris et al. 1984, 1985; } \\
\text { Taylor and Mangan 1987; Taylor 1988a,b; } \\
\text { Taylor et al. 1991; M. F. Chaudhury } \\
\text { and J. B. Welch, personal communication 2013) }\end{array}$ \\
\hline & $\begin{array}{l}\text { Cellulose-fibre-based } \\
\text { diet }\end{array}$ & $\begin{array}{l}\text { Whole bovine blood powder, } \\
\text { poultry egg powder } \\
\text { and milk powder }\end{array}$ & $\begin{array}{l}\text { Cellulose fibre (CF-100) } \\
\text { from recycled paper }\end{array}$ & $\begin{array}{l}\text { Used in the Mexican plant (Chaudhury } \\
\text { et al. 2002; Chaudhury and Skoda 2007) }\end{array}$ \\
\hline \multirow[t]{2}{*}{ Adult } & $\begin{array}{l}\text { Lean meat and } \\
\text { honey diet }\end{array}$ & $\begin{array}{l}\text { A mixture of ground horse } \\
\text { meat and honey }\end{array}$ & NA & $\begin{array}{l}\text { Used in the plants in Florida, Texas and } \\
\text { Mexico (Smith 1960; Baumhover } \\
\text { et al.1966; Marroquin 1985) }\end{array}$ \\
\hline & Dry powder diet & $\begin{array}{l}\text { Sucrose, dried egg powder } \\
\text { or milk powder }\end{array}$ & NA & $\begin{array}{l}\text { Used in the plants of Mexico and Panama } \\
\text { (Marroquin 1985; M. F. Chaudhury, } \\
\text { unpublished data) }\end{array}$ \\
\hline
\end{tabular}


method was not practical for mass rearing. Therefore, formaldehyde was added to prevent the putrefaction of media to an acceptable degree. Depending on the larval density, the weights of pupae from this media ranged between 40 and $60 \mathrm{mg}$, with an average $45 \mathrm{mg}$. The estimated cost was less than 30 cents/ 1000 larvae (Melvin and Bushland 1936).

For mass production at the Bithlo and Sebring plants in Florida, milk was removed because of the volume and required cold storage (Melvin and Bushland 1940). The formulation was changed to $1000 \mathrm{ml}$ water, $6 \mathrm{ml}$ formalin, $500 \mathrm{ml}$ citrated beef blood and $1000 \mathrm{~g}$ ground lean meat (Melvin and Bushland 1940; Graham and Dudley 1959; Smith 1960; Baumhover et al. 1966). To improve survival and growth of young larvae, plasma instead of whole blood was used in the starting medium for the first $30 \mathrm{~h}$ (Baumhover et al. 1966). Based on price and supply, beef, whale and horse meats were used in the plants (Smith 1960) although ground muscle of certain animals (sheep, hog, chicken, rabbit, sparrow, dove and catfish; Melvin and Bushland 1940), whole nutria and pig lungs (Gingrich 1972) could be used to produce the screwworms of an acceptable size. The study also showed that the bloods of goat, sheep and hog could be used instead of the beef blood. The cost for this non-milk recipe was less than 50 cents/1000 larvae (Melvin and Bushland 1940).

The lean-meat diets made from various muscles are suitable for both laboratory and large-scale rearing. However, lean meats are expensive and supplies in large amount are not stable because of competition from human consumption and animal food industry. Fresh raw meats, liquid blood and milk require the added costs (purchase and maintenance in operation) of cold storage before processing into the diet.

\section{Liquid larval diet}

The development of liquid media for mass rearing was initialized in Mission, Texas, in 1962 (Williams 1975) because of unsustainable supply, high price and required cold storage of meats. With a $3-\mathrm{cm}$ layer of unbleached cotton to hold the liquid and larvae, Gingrich et al. (1971) reported three formulations, namely the starting medium $(2-3 \%$ dried whole chicken egg, 5-6\% dried whole bovine blood, 1.6-4\% calf suckle (dried milk manufactured by Albers Milling Co., Portland, OR, USA) and $0.2 \%$ formalin, used for the first $48 \mathrm{~h}$ ), the intermediate medium (the same ingredients except $0.5 \%$ sucrose replaced the whole egg, fed for the next $48 \mathrm{~h}$ ) and the finishing medium (the same as the intermediate one with $1 \%$ sucrose and 3\% dried cottage cheese, supplied for the rest of the development time). Later, these formulations were simplified as the standard liquid medium (6\% dried whole blood, 3\% dried whole egg, 3\% calf suckle, $2 \%$ dried cottage cheese and $0.25 \%$ formalin) for plant use in Mission, Texas and Tuxtla Gutierrez, Mexico (Brown and Snow 1979).

As dried cottage cheese was the most expensive ingredient and had the most difficulty to be formulated into the medium, Brown and Snow (1979) replaced $2 \%$ cottage cheese with an additional $3 \%$ dried whole blood (total 9\%) in the liquid medium used in both Mission and Mexico plants. With more trials, non-fat dry milk was used to replace calf suckle (Harris et al. 1984). Using the curvilinear model, Taylor (1988a) demonstrated that the optimal composition of $6 \%$ blood, $5 \%$ egg and $1.3 \%$ milk in the liquid diet maximized the screwworm life history parameters of biomass, survival, emergence and fecundity. Beginning in 1983, acetate fibres instead of cotton were suspended into the liquid diet to support the larvae in the later hydroponic rearing system in Mexico (Marroquin 1985; Taylor et al. 1991). The nutritional ingredients cost less than 14 cents/1000 larvae (Gingrich 1972) but the whole diet, including acetate, was priced at 34 cents/1000 larvae (Taylor et al. 1991).

The system required large space and was labourintensive (because of needed diet change every $4 \mathrm{~h}$ ), making quality control more difficult; the liquid diet system encountered the problems of small larval size, waste contamination, premature or delayed larval crawl-off (Marroquin 1985).

\section{Gelled larval diet}

Harris et al. (1984, 1985) developed and adapted a gelled diet containing the polyacrylamide polyacrylate copolymers (Water Lock ${ }^{\circledR}$ G-400; Grain Processing Corp., Muscatine, IA, USA) to eliminate or improve the issues such as waste contamination, poor quality control of larvae and labour-intensive process of liquid exchange in the hydroponic rearing system. The gelled diet used in mass production consisted of $6-7 \%$ dried blood, 3\% dried egg, 3-5\% non-fat dried milk, $0.1 \%$ formalin and $1.0-1.2 \%$ Water Lock ${ }^{\circledR}$ G400. Spray-dried animal blood cells (with higher protein contents and solubility, but lower price) or locally available mechanically defibrinated bovine blood could be used as alternative sources of blood proteins in the diet (Chaudhury et al. 1998, 2011). Among the tested gelling agents, Water Lock ${ }^{\circledR}$ G-400 had several advantages in terms of cost, handling and preparation (Harris et al. 1984, 1985; Taylor and Mangan 1987; 
Taylor 1988b). The price of the gelled diet was 24 cents/1000 larvae (Taylor et al. 1991). At a onefourth price of Water Lock ${ }^{\circledR}$ G-400, a brown granular powder of Super-Absorbent (a starch-grafted sodium polyacrylate polymer, Hampton Roads Repackaging, Chesapeake, VA, USA) was also tested as a promising gelling agent for screwworm mass production (Chaudhury and Alvarez 1999) but was not adopted. A lessexpensive polyacrylate gel, Aquatain (Pioneer Medical Inc., Lakeland, FL, USA), was used at $1.8 \%$ concentration later in the production plants in Mexico (1999 prices were Water Lock ${ }^{\circledR}$ G-400 at $8.25 / \mathrm{kg}$, Aquatainat $5.00 / \mathrm{kg}$ and the diet with Aquatain at 25.70 cents/ 1000 larvae; Chaudhury et al. 2002) and Panama (Aquatain at $\$ 8.03 / \mathrm{kg}$ in 2013; J. Welch, personal communication).

Compared to the hydroponic rearing system, the gelled-diet system did not use the cotton or acetate mats and reduced labour and the amount of diet used (Taylor 1992). On the other hand, the solidifying gels are not biodegradable in the environment. Also, the gels may accumulate and clog the pipes of the waste disposal system.

\section{Fibre-based larval diet}

As bulking agents, the recycled newsprint product (Terra-Mulch; Profile Product LLC, Buffalo Grove, IL, USA) and cellulose fibre (CF-100; Central Fiber Corp., Wellsville, KS, USA) replaced the gelling materials because they were the most expensive ingredients in the gelled diets (Chaudhury et al. 2002; Chaudhury and Skoda 2007). The diet ingredients included 6\% spray-dried blood, $4 \%$ spray-dried egg, $4 \%$ dried milk, $0.1 \%$ formalin as the preservative and $6 \%$ Terra Mulch or $5 \%$ CF-100 as the bulking agent. The costs of the diets with Terra-Mulch or CF-100 were 19 and 22 cents/ 1000 larvae, respectively.

Besides the lower price, the fibre bulking agents are easier to handle and use in the diet preparation. Furthermore, they are environmentally friendly and may be disposed of in a landfill without any further processing. Although there is more release of the metabolic waste ammonia from the fibres than the gels used as the bulking agents during the plant rearing process, this is being addressed in ongoing research by the USDA-ARS scientists (A. Sagel and M. F. Chaudhury, unpublished data).

\section{Adult diets}

Although exogenous protein is not required by the screwworm female adult for egg development during the first gonotrophic cycle because her protein reserve from larva is used, female flies visited carrion and wounds in the wild (Crystal 1967), and when fed meridic diets, produced significantly heavier eggs, compared with flies fed only honey (Brewer 1993). During the early stage of adulthood, dietary protein or raw meat supplemented in the adult diet sped up egg maturation (although this may induce the issue of early oviposition in mass production), increased the percentage of gravid females and the number of eggs per female (Thomas 1993; Hammack 1999; Sagel et al. 2002).

For adult screwworm colony maintenance and egg production, a mixture of equal parts of ground lean horse meat and honey, honey and water were provided in the fly cages in the plants in Florida (Smith 1960; Baumhover et al.1966), Texas and Mexico. The flies carried and dropped honey in the cages, causing moulds on the internal surfaces of the cages. Brewer (1993) reported three formulations of gelled adult diets, consisting of sucrose, egg powder, non-fat milk powder and whole bovine blood powder, bulked by $1.1 \%$ Water Lock ${ }^{\circledR}$ G-400 or 3.6\% Grit-O' Cob (a corn cob product; Andersons Inc., Maumee, OH, USA). Chaudhury et al. (2000) published a formulation with spray-dried egg powder, honey and molasses at a significantly lower price. These gelled and molasses diets for flies were tested in laboratory and showed promising results for both small-scale and mass-rearing application. As a back-up adult diet in the Mexican plant, granulated sugar and milk powder ( $1: 1)$ were tested for three generations, and no detriment to egg production was found (Marroquin 1985). The dry adult diets with sucrose and dried egg powder in various ratios were also tested in the Mexican plant around 2004 and the $1: 1$ ratio was adopted in the Panamanian plant in 2007 (M. F. Chaudhury, unpublished data). These diets in dry powder eliminate the mould issue in the fly cages.

\section{Future Prospects for the Screwworm Diets}

Understanding the essential needs of the species for better formulations of screwworm diets

Diet formulation and chemical definition are two common methods used to evaluate insect dietary nutrition (Schultz et al. 1946; Singh 1977; Cohen 2004; Schneider 2009). The majority of screwworm researchers used the first approach because it is more practical for diet preparation/application in the production plant (Melvin and Bushland 1936, 1940; Gingrich et al. 1971; Taylor 1988a; Chaudhury et al. 1998). However, the chemically defined approach 
could pinpoint individual chemical nutrients required for optimum larval growth and maturation (Gingrich 1964) and, thus, allow for practical and effective substitutions of ingredients.

To evaluate the diet quality, the life history parameters including weight of mature larva (mg), pupal weight $(\mathrm{mg})$, number of pupae per tray, biological yield (\%), adult emergence rate, eggs laid (mg), egg hatch rate and adult longevity (d) were measured (Taylor 1988a,b; Chaudhury et al. 2011). There are two issues with these parameters used in the screwworm research: (i) measuring these parameters is time-consuming and some of them may be highly correlated; and (ii) none of the parameters directly indicates the quality of males in relation to their performance in field eradication programme (Pitti et al. 2011).

Recent advances in biomolecule analyses, such as high-pressure liquid chromatography (HPLC) and mass spectrometry in protein sequencing, identification and profiling, have emerged and been gaining popularity in the research and application of food science and biology (Domon and Aebersold 2006). Use of these techniques will reveal the biochemical components of the screwworm's body and may help better define the screwworm's nutritional needs. With various analytical procedures, Duarte et al. (1999) and Marquez et al. (2005) reported the nutrient composition of bovine blood. The nutrient 'standard reference' data of different kinds of beef, dry whole egg and dry milk are available online in the USDA National Nutrient Database (Nutrient Data Lab 2011). These compositional data of diet ingredients are necessary for both economical improvement of the screwworm diet formulations and efficient balance of the required nutrients in larval and adult diets. To deal with the changes in diet ingredient supply and to control the diet cost effectively, more proper experimental design and relevant statistical analyses have been developed for diet formulation (Lapointe et al. 2008).

\section{Feeding stimulants}

The presence of an unidentified feeding stimulant or stimulants in the artificial diets is critical, particularly in larval screwworms, for successful rearing. Without the animal blood ingredients (whole blood, plasma or dried blood cells) in the non-meat diets, the larvae did not feed well and failed to reach pupal stage (M. F. Chaudhury, unpublished data). Research to pinpoint the stimulant chemicals is ongoing by the USDA-ARS scientists and will be helpful to improve the diets using non-animal-derived proteins at lower price.

\section{Development of new formulations from alternative or local protein sources}

Less-expensive locally available or plant-derived proteins could be solutions to lower cost of diets. In nature, screwworms are obligate parasites of warmblood animals. Larvae feed on the flesh and muscles near wounds and their food is generally high in proteins and low in fat. Therefore, animal-derived proteins such as lean meats, blood products, milk products and egg products have been used as the main ingredients in the screwworm diets. Fishmeal containing $60-70 \%$ crude protein by weight is cheaper and locally produced in Central America. As a protein source, fishmeal has been successfully tested to replace dry milk in the screwworm diet in Panama (A. Sagel, M. F. Chaudhury, P. L. Phillips and S. R. Skoda, unpublished data). Regarding plant-derived proteins, Friese (1992) reported an acceptable and potential use of spray-dried powder of the microalgae, Spirulina maxima, replacing the non-fat dry milk in the screwworm diet. Spirulina powder consists of $60-70 \%$ protein, and Spirulina spp. can be commercially cultivated. With better understanding of the screwworm nutrition and feeding behaviour, soybean meal, which is composed of promising ingredients (44 $50 \%$ protein, $\sim 1 \%$ fibre and $\sim 1 \%$ fat) and widely available in both North and South Americas, should be tested as another possible low-cost source of plant proteins.

\section{Waste diet management}

Water Lock ${ }^{\circledR}$ G-400 and Aquatain used as bulking agents in the diets are of low degradability, persisting in the environment for an extensive time (EPA 2010). In the Panamanian plant, a tank of $6200 \mathrm{~m}^{3}$ was built on site to store the spent and autoclaved Aquatain. Further process of this waste is unknown yet. To avoid this issue, fibre-based bulking agents were tested and successfully used in the screwworm mass rearing (Chaudhury et al. 2002; Chaudhury and Skoda 2007).

The screwworms are mass-reared on the proteinrich diets in the bio-secured plants. As a consequence, ammonia gas is liberated as a main waste during the protein metabolic processes and reaches significant levels in the final rearing room. Therefore, the ammonia becomes problematic to the rearing environment, affecting not only the workers but also the quality of the insect. Mechanical and chemical methods have been tested to reduce the ammonia concentrations in the rearing rooms. Air circulation and ventilation 
were improved in the rooms, potassium permanganate $\left(\mathrm{KMnO}_{4}\right)$ instead of formaldehyde is being tested as the preservative in the larval diet and to lower the ammonia emission, and extract of a perennial plant, Yucca, is being tested to further lower the ammonia emissions (A. Sagel et al., unpublished data).

In summary, four larval diet and two adult diet formulations have been used in the six screwworm production plants so far. Given the fluctuations of diet ingredient price and supply in the market and new tools for insect diet development, more research on the screwworm nutrition, alternative protein sources, diet formulations and relevant pollution/waste reduction is needed to mass produce the screwworms more effectively and efficiently.

\section{Acknowledgements}

We thank John Welch (USDA-APHIS) and John Foster (Univ. of Nebraska-Lincoln) for their suggestions and critical reading of the manuscript.

\section{References}

Baumhover A, 2002. A personal account of developing the sterile insect technique to eradicate the screwworm from Curacao, Florida and the southeastern United States. Fla. Entomol. 85, 666-673.

Baumhover A, Husman C, Graham A, 1966. Screwworms. In: Insect colonization and mass production. Ed. by Smith C, Academic Press, New York, London, 533554.

Brewer F, 1993. Meridic diets for adult screwworm (Diptera: Calliphoridae). J. Entomol. Sci. 28, 197-204.

Brown H, Snow J, 1979. Screwworm (Diptera: Calliphoridae): a new liquid medium for rearing screwworm larvae. J. Med. Entomol. 16, 29-32.

Chaudhury M, Alvarez L, 1999. A new starch-grafted gelling agent for screwworm (Diptera: Calliphoridae) larval diet. J. Econ. Entomol. 92, 1138-1141.

Chaudhury M, Skoda S, 2007. A cellulose fiber-based diet for screwworm (Diptera: Calliphoridae) larvae. J. Econ. Entomol. 100, 241-245.

Chaudhury M, Alvarez L, Welch J, 1998. An alternative source of blood protein for screwworm (Diptera: Calliphoridae) larval diet. J. Econ. Entomol. 91, 13971400 .

Chaudhury M, Alvarez L, Velazquez L, 2000. A new meatless diet for adult screwworm (Diptera: Calliphoridae). J. Econ. Entomol. 93, 1398-1401.

Chaudhury M, Alvarez L, Velazquez L, 2002. Recycled paper products as substitutes for gelling agent in Screwworm (Diptera: Calliphoridae) larval diet. J. Econ. Entomol. 95, 1337-1341.
Chaudhury M, Skoda S, Sagel A, 2011 . Solidifying agent and processing of blood used for the larval diet affect screwworm (Diptera: Calliphoridae) life-history parameters. J. Econ. Entomol. 104, 1103-1107.

Cohen A, 2004. Insect diets science and technology. CRC Press, Boca Raton, London, New York, Washington DC.

Crystal M, 1967. Reproductive behavior of laboratoryreared screw-worm flies (Diptera: Calliphoridae).

J. Med. Entomol. 4, 443-450.

Domon B, Aebersold R, 2006. Mass spectrometry and protein analysis. Science 312, 212-217.

Duarte R, Simoes M, Sgarbieri V, 1999. Bovine blood components: fractionation, composition, and nutritive value. J. Agric. Food Chem. 47, 231-236.

EPA, 2010. Marine Debris Timeline. http://www.epa.gov/ gmpo/edresources/debris_t.html [accessed on June 2013].

FAO, 1992. The new world screwworm eradication programme: North Africa 1988-1992. Food and Agriculture Organization of the United Nations, Rome, Italy.

Friese D, 1992. Microalgae Spirulina maxima (Oscillatoriaceae) in the larval diet of the screwworm (Diptera: Calliphoridae). Southwest. Entomol. 17, 289-293.

Gingrich R, 1964. Nutritional studies on screw-worm larvae with chemically defined media. Ann. Entomol. Soc. Am. 57, 351-360.

Gingrich R, 1972. Nutritional studies: their bearing on the development of practical oligidic diet for mass rearing larvae of the screwworm, Cochliomyia hominivorax. In: Insect and mite nutrition. Ed. by Rodriguez J, N. Holland, Amsterdam, 257-268.

Gingrich R, Graham A, Hightower B, 1971. Media containing liquefied nutrients for mass-rearing larvae of the screw-worm. J. Econ. Entomol. 64, 678-683.

Goodenough J, Brown H, Wendel L, Tannahill F, 1983. Screwworm eradication program: a review of recent mass-rearing technology. Southwest. Entomol. 8, 16-31.

Graham O, 1985. Symposium on eradication of the screwworm from the United States and Mexico. Entomological Society of America, College Park.

Graham A, Dudley F, 1959. Culture methods for mass rearing of screw-worm larvae. J. Econ. Entomol. 52, 1006-1008.

Hammack L, 1999. Stimulation of oogenesis by proteinaceous adult diets for screwworm, Cochliomyia hominivorax (Diptera: Calliphoridae). Bull. Entomol. Res. 89, 433440.

Harris R, Peterson R, Vazquez-Guevara M, Graham O, 1984. Gelled media for the production of screwworm larvae. Southwest. Entomol. 9, 257-262.

Harris R, Gersabeck E, Corso C, Graham O, 1985. Screwworm larval production on gelled media. Southwest. Entomol. 10, 253-256.

Knipling E, 1985. Sterile insect technique as a screwworm control measure: the concept and its development. 
In: Symposium on eradication of the screwworm from the United States and Mexico. Ed. by Graham O, Entomological Society of America, College Park, 4-7.

Lapointe S, Evens T, Niedz R, 2008. Insect diets as mixtures: optimization for a polyphagous weevil. J. Insect Physiol. 54, 1157-1167.

Marquez E, Bracho M, Archile A, Rangel L, Benitez B, 2005. Proteins, isoleucine, lysine and methionine content of bovine, porcine and poultry blood and their fractions. Food Chem. 93, 503-505.

Marroquin R, 1985. Mass production of screwworms in Mexico. In: Symposium on eradication of the screwworm from the United States and Mexico. Ed. by Graham O, Entomological Society of America, College Park, 31-36.

Mastrangelo T, Welch J, 2012. An overview of the components of AW-IPM campaigns against the New World screwworm. Insects 3, 930-955.

Melvin R, Bushland R, 1936. A method of rearing Cochliomyia americama C. \& P. on artificial media. USDA Bur. Entomol. Plant Quar. ET-88.

Melvin R, Bushland R, 1940. The nutritional requirements of screwworm larvae. J. Econ. Entomol. 33, 850-852.

Nutrient Data Lab, 2011. USDA National Nutrient Database. http://ndb.nal.usda.gov/ [accessed on June 2013].

Pitti A, Skoda S, Kneeland K, Berkebile D, Molina-Ochoa J, Chaudhury M, Youm O, Foster J, 2011. Effect of adult screwworm male size on mating competence. Southwest. Entomol. 36, 47-60.

Sagel A, Berkebile D, Foster J, Skoda S, 2002. The optimum diet of spray-dried animal blood cells as protein source for adult screwworms (Diptera: Calliphoridae). J. Entomol. Sci. 37, 353-362.

Schneider J, 2009. Principles and procedures for rearing high quality insects. Mississippi State University, Starkville.

Schultz J, Lawrence P, Newmeyer D, 1946. A chemically defined medium for the growth of Drosophila melanogaster. Anat. Rec. 96, 540.
Singh P, 1977. Artificial diets for insects, mites, and spiders. Plenum Press, New York, Washington, London.

Smith C, 1960. Mass production of screw-worm (Callitroga hominivorax) for the eradication program in the southeastern states. J. Econ. Entomol. 53, 1110-1116.

Taylor D, 1988a. Response of screwworms (Diptera: Calliphoridae) to changes in the concentration of blood, egg, and milk in the larval diet. J. Econ. Entomol. 81, 562567.

Taylor D, 1988b. Comparison of two gelling agents for screwworm (Diptera: Calliphoridae) larval diets. J. Econ. Entomol. 81, 1414-1419.

Taylor D, 1992. Rearing systems for screwworm mass production. In: Advances in insect rearing for research and pest management. Ed. by Anderson T, Leppla N, Westview Press, Boulder, San Francisco, Oxford, 393-403.

Taylor D, Mangan R, 1987. Comparison of gelled and meat diets for rearing screwworm, Cochiliomyia hominivorax (Diptera: Calliphoridae), larvae. J. Econ. Entomol. 80, 427-432.

Taylor D, Bruce J, Garcia R, 1991. Gelled diet for Screwworm (Diptera: Calliphoridae) mass production. J. Econ. Entomol. 84, 927-935.

Thomas D, 1993. Fecundity and oviposition in laboratory colonies of the screwworm fly (Diptera: Calliphoridae). J. Econ. Entomol. 86, 1464-1472.

Whitten C, 1985. Screwworm research activities in the United States during the period 1958-84. In: Symposium on eradication of the screwworm from the United States and Mexico. Ed. by Gramham O, Entomological Society of America, College Park, 16-21.

Williams D, 1975. Progress in screwworm eradication in the United States. Proceedings of Symposium on Ectoparasites. Centro Internacional de Agricultura Tropical (CIAT), Cali, Colombia, 25-30. 